\title{
Evaluation of Coupons from Tank 50 (U)
}

by

J. I. Mickalonis

Westinghouse Savannah River Company

Savannah River Site

Aiken, South Carolina 29808

DOE Contract No. DE-AC09-89SR 18035

This paper was prepared in connection with work done under the above contract number with the U.S.

Department of Energy. By acceptance of this paper, the publisher and/or recipient acknowledges the U.S. Government's right to retain a nonexclusive, royalty-free license in and to any copyright covering this paper, along with the right to reproduce and to authorize others to reproduce all or part of the copyrighted paper. 


\section{DISCLAMIER}

Portions of this document may be illegible in electronic image products. Images are produced from the best available original document. 
DISTRIBUTION:

J. E. Marra, 703-H

H. A. Abodishish, 703-H

T. C. Hsu, 703-H

L. S. Livingston, 703-H

F. G. McNatt, 704-8H

W. B. Van Pelt, 241-152H

T. L. Ortner, 241-152H

M. Rios-Armstrong, 241-152H

C. D. Cowfer, 730-B

W. L. Tamosiatis, 773-A

J. N. Brooke, 719-4A

D. T. Hobbs, 773-A

T. L. Capeletti, 773-41A

N. C. Iyer, 773-A

B. J. Wiersma, 773-A

P. E. Zapp, 773-A

R. L. Sindelar, 773-41A

C. F. Jenkins, 730-A

D. K. Appel, 773-A

Document Control, 703-43A (4) 
WSRC-TR-95-0352

EVALUATION OF COUPONS FROM TANK 50 (U)

By

John I. Mickalonis

September, 1995

Patent Status: This internal management report is being transmitted without DOE patent clearance, and no further dissemination or publication shall be made of the report without prior approval of the DOE-SR patent counsel

Westinghouse Savannah River Company Aiken, SC 29808

PREPRARED FOR THE U.S. DEPARTMENT OF ENERGY UNDER CONTRACT DE-AC09-89SR18035

PRESENTLY UNDER CONTRACT DE-AC09-89SR18035 


\section{DISCLAIMER}

This report was prepared as an account of work sponsored by an agency of the United States Government. Neither the United States Government nor any agency thereof, nor any of their employees, makes any warranty, express or implied, or assumes any legal liability or responsibility for the accuracy, completeness, or usefilness of any information, apparatus, product, or process disclosed, or represents that its use would not infringe privately owned rights. Reference herein to any specific commercial product, process, or service by trade name, trademark, manufacturer, or otherwise does not necessarily constitute or imply its endorsement, recommendation, or favoring by the United States Government or any agency thereof. The views and opinions of authors expressed herein do not necessarily state or reflect those of the United States Government or any agency thereof.

This report has been reproduced directly from the best available copy.

Available to DOE and DOE contractors from the Office of Scientific and Technical Information, P.O. Box 62, Oak Ridge, TN 37831; prices available from (615) 576-8401.

Available to the public from the National Technical-Information Service, U.S. Department of Commerce, 5285 Port Royal Road, Springfield, VA 22161. 
APPLIED SCIENCE \& ENGINEERING TECHNOLOGY

Keywords: Corrosion Monitoring Pitting Carbon Steel Waste Tank Corrosion Rate

Retention: 20 years

EVALUATION OF COUPONS FROM TANK 50 (U)

by

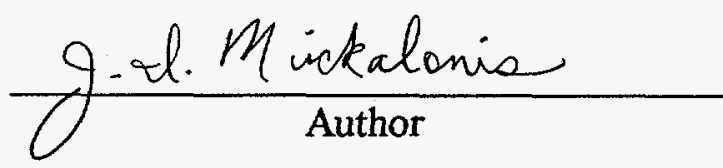

ISSUED: SEPTEMBER, 1995

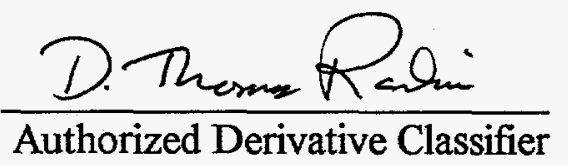

$8 / 3 / 155$

Authorized Derivative Classifier

Date

SRTC Savannah River Technology Center, Aiken, SC, 29808

Westinghouse Savannah River Company

Prepared for the U. S. Department of Energy under Contract DE-AC09-89SR18035 
DOCUMENT: WSRC-TR-95-0352

TITLE: EVALUATION OF COUPONS FROM TANK 50 (U)

\section{APPROVALS}

Bunce LI theesma

DATE: $\quad 8-31.95$

B. J. Wiersma, Technical Reviewer

SRTC/ASET/Materials Technology Section

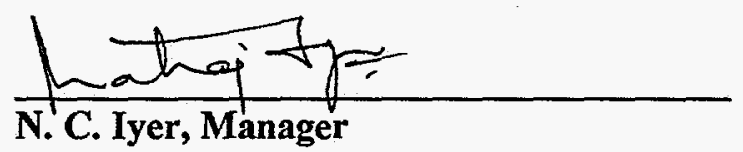

DATE: $\quad 8-31-95$

Materials Application and Corrosion Technology

SRTC/ASET/Materials Technology Section

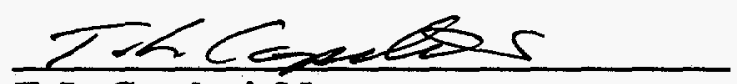

DATE: $8 / 3 / 2 \pi-$

T. L. Capeletti, Manager

Materials Technology Section 


\section{TABLE OF CONTENTS}

SUMMARY 1

INTRODUCTION 1

COUPON DESCRIPTION

COUPON EVALUATION 2

Prior To Removal 2

Before Cleaning 2

Weight Losses $\quad 2$

After Cleaning 3

DISCUSSION 3

CONCLUSION 4

REFERENCES

TABLES 5

$\begin{array}{lc}\text { FIGURES } & 8\end{array}$ 


\section{LIST OF TABLES}

1 The Exposure Condition and Corrosion For The Tank 50

Coupons Before Cleaning

2 Weight Losses And Average Corrosion Rates For Tank 50 Coupons 6

3 The Exposure Condition and Corrosion For The Tank 50

Coupons After Cleaning

\section{LIST OF FIGURES}

1 Floating rack of the Coupon Corrosion Rig from tank 50

2 Back view of the corroded welded pipe coupon (CW-1)

which was exposed to air

3 Back view of the corroded pipe coupon (C-1) which was exposed to the waste

4 Back view of the corroded plate coupons

5 Front view of the corroded welded plate coupons. (W-1 and W-2) which were exposed mostly to the waste 


\section{EVALUATION OF COUPONS FROM TANK 50 (U)}

\section{SUMMARY}

The coupons from the corrosion coupon rig (CCR) were removed from tank 50 after a ten-month exposure. The evaluation consisted of microscopic examination, weight losses, and pit depth measurements. The coupons were exposed in both the liquid waste and the air space above the waste. The corrosion in the air space was characterized by variabledepth degradation under adherent corrosion products. Corrosion degradation was not significant for coupons in the waste. The coupon areas exposed at the air-waste interface had pits; the deepest measuring 6 mils. These results provide current information on actual corrosion in the waste tank. Continued use of the CCR on tank 50 is recommended (i) to monitor pitting rates, (ii) to verify the low corrosion degradation of the tanks, and (iii) to complete the CCR development for future implementation in tanks 43 and 48.

\section{INTRODUCTION}

Corrosion coupon rigs are used to monitor corrosion conditions of storage or process vessels. A CCR was fabricated for tank 50 as a preliminary trial for use in the tank farm. Tank 50 was chosen because of the low levels of contamination. The CCR was placed on tank 50 during May, 1994 and removed during March, 1995. The coupon rack floated sideways during the exposure [1]. The CCR was transported to SRTC for coupon removal and corrosion evaluation. This memo reports the findings of that investigation.

\section{COUPON DESCRIPTION}

The coupons that were placed on the rack were prepared with conditions that simulated the fabrication of Type III waste tanks and the cooling coils. The tank wall coupons were made of normalized ASTM A537, Class 1 plain carbon steel plate. The pipe coupons, representative of the cooling coils, were made of normalized A106, Grade B, schedule 40 plain carbon steel pipe. The documented welding procedures were followed to make the welded coupons.

The coupons were saw cut from either plate sections or pipes. The plate coupons were 8" by 1 " by $0.125^{\prime \prime}$ and the pipe coupons were $8^{\prime \prime}$ by $0.75^{\prime \prime}$ by $0.154^{\prime \prime}$. Edges were rounded with a belt sander. The coupons were surface finished to 600 grit prior to stress relieving and numerically stamped. Holes were also drilled at each end of the coupon for attaching to the rack. Each coupon was photographed, weighed, and dimensionally measured.

The initial surfaces of the various coupons differed. The A537 plate coupons had a blackgray oxide which also covered the edges. Both welded and unwelded coupons had smooth surfaces. The A106 pipe coupons had rough pock-marked surfaces. The unwelded pipe coupons had a thick black oxide scale that appear sooty; these coupons were not stress relieved. The welded pipe coupons, however, had an oxide similar to the A537 coupons. 
The weld bead could be clearly seen on the pipe coupons. The edges of the pipe coupons had a shiny metallic finish, resulting from the sanding operation.

\section{COUPON EVALUATION}

The coupon evaluation consisted primarily of visual examination and was performed at several stages. These stages were prior to removal from the floating rack, after removal, and after cleaning of corrosion products. The coupons were examined before and after cleaning with a stereomicroscope. Photographs were taken at each stage. Pit depth measurements were made using a digitized microscope. The coupons were cleaned according to ASTM G1-88, "Standard Practice for Preparing, Cleaning, and Evaluating Corrosion Test Specimens" [2]. The cleaning solution was a sodium hydroxide solution with granulated zinc. Coupon weights were measured after cleaning to calculate weight losses and average corrosion rates.

\section{Prior To Removal}

Since the coupon rack was lopsided during the exposure, two samples were completely immersed in the waste, one sample was exposed only to the air, and three samples were exposed to both the waste and the air. Table 1 gives the number, material, welding and exposure condition, and a description of the corrosion products for each coupon. Figure 1 is a photograph of the rack before the coupons were removed. The air-waste interface can. be clearly seen in the photograph.

\section{Before Cleaning}

The corrosion degradation of the coupons, as described in Table 1, was directly affected by the exposure conditions and the material. Figures 2-5 are photographs of the corroded surfaces of each of the coupons. The sections of coupons (CW-1 and P-2) that were exposed to the air had greater degradation than those exposed to the waste. The airexposed sections had tubercle corrosion in which corrosion products built up on the surface to form a tube or mound. Occluded cells form and maintain or increase the corrosive conditions. The waste-exposed sections (C-1, P-1, W-1, and W-2) had either pinpoints or spots of rust. The coupons that were exposed to the waste tended to have a brownish tint. The coupons with an air-waste interface (P-2, W-1, and W-2) had a white residue in this region. The oxide on A537, which was formed during the stress relieving operation, appeared to be more protective than the as-extruded surface on A106.

\section{Weight Losses}

Prior to cleaning the exposed coupons, unexposed coupons or blanks were cleaned to measure weight loss attributable to the cleaning solution. The weight loss was dependent on the type of coupon. The weight losses for the blanks were as follows: $0.1 \mathrm{~g}$ for the plate, $0.3 \mathrm{~g}$ for the welded pipe, and $1.1 \mathrm{~g}$ for the unwelded pipe. The absence of the heat formed oxide on the unwelded pipe probably allowed greater attack by the cleaning 
solution. These weight losses were used to adjust the weight losses of the exposed coupons.

The weight losses and average corrosion rates were affected by both the exposure condition and the material as shown in Table 2 . The corrosion rate in the vapor space was greater than that in the waste as seen by comparing the rates for CW-1 and P-2 with the other coupons. A537 had a significantly lower corrosion rate than A106. The overall averages for A537 and A106 were 0.075 and $0.25 \mathrm{mpy}$, respectively. The small values of the corrosion rates indicated that general corrosion was negligible during the ten-month exposure. This result supports the NDE findings that general corrosion in the waste tank is not a significant factor with respect to structural integrity.

\section{After Cleaning}

The surface and corrosion morphology were investigated after the corrosion products were removed by cleaning. Table 3 gives the number, material, welding and exposure condition, and a description of the surface morphology for each coupon. In general, irregular pit-like surfaces were observed on sections exposed to the air, while wasteexposed sections were slightly attacked at rust spots.

On the air-exposed sections for CW-1 and P-2, variable-depth corrosion was observed beneath the mounds of corrosion products. Variable-depth corrosion is characterized by broad, nonuniform holes in the material. The surface area of a hole may be about $0.05 \mathrm{in}^{2}$. The largest measured depths were 7.5 and 6 mils for CW-1 and P-2, respectively. The initial rough surface of CW-1 made the depth measurements for this coupon questionable. For P-2, the 6 mil depth was located in the interfacial region where most depths were in the range of 2-4 mils. Areas with adherent oxide layers did not corrode.

The waste-exposed coupons did not have significant corrosive attack. The pipe coupon, $\mathrm{C}-1$, had a rough surface, but as explained above the rough surface was typical of the initial surface. For the plate coupon, the initial grinding marks and oxide were still observed. Slightly attacked areas were beneath the rust spots.

The interfacial regions on $\mathrm{W}-1$ and $\mathrm{W}-2$ were where pits were observed. The deepest pits that were measured were 2 and 3.7 mils, although most pits ranged between 1-2 mils. The waste-exposed sections of these coupons were slightly attacked showing a rough surface where rust spots were located.

\section{DISCUSSION}

The corrosion processes that occurred in the waste tank were similar to those observed in the laboratory during partial-immersion coupon tests. These processes were variable-depth corrosion on air-exposed sections and minimal attack on waste-exposed sections. In the laboratory, rust spots were not typically observed on waste-exposed sections for properly 
inhibited solutions. The rust spots on the coupons may have occurred after removal when residual rinse water remained on the surface.

The interfacial region has been the area of concern because hydroxide concentrations may be tenuous due to carbon dioxide absorption. The steel would be susceptible to pitting with insufficient inhibitors. The concentration ranges of the primary constituents in tank 50 during the ten-month exposure were 2.4-3.5 $\mathrm{M}$ for nitrate, $1.5-2.0 \mathrm{M}$ for hydroxide, and 0.06-0.1 $\mathrm{M}$ for nitrite. Pitting may have occurred due to the low nitrite concentration.

The deepest measured pit on the coupons was 6 mils. If this rate is maintained a wall that is 0.5 inch thick would be penetrated in approximately 70 years. The constancy of this rate is an unknown. Pit growth may cease if the pit passivates or may continue depending on the waste conditions. Corrosion monitoring, therefore, would provide the information for assessing the corrosion state of the waste tanks.

The use of the CCR in tank 50 should be continued to complete the development of this corrosion monitoring tool for the waste tanks. Subsequent placement of a CCR into tanks 43 and 48 is recommended since the conditions in these tanks will be variable and possibly corrosive. Tank 48 is the processing tank for ITP and tank 43 is the recycle tank for DWPF, although in tank 43 various waste streams will be received. The CCR is a technique where the cumulative effect of these conditions could be detected and the corrosion mitigated.

\section{CONCLUSION}

The coupons from tank 50 have provided direct information on the actual corrosion occurring in a waste tank. This corrosion consisted of variable depth corrosion on airexposed sections and pitting in interfacial regions. The pitting rate was not excessive, but should be monitored to verify that low rates are obtained and tank integrity is not compromised. The corrosion rate on air-exposed steel was greater than that measured in the waste, although the overall rates were low. These result are consistent with previous experimental finding and NDE measurements of the waste tanks. The development of the CCR should be completed on tank 50 so that waste tank conditions can be effectively monitored for corrosion. CCR placement into tanks 43 and 48 should follow since these tanks have variable conditions which may induce corrosion.

\section{REFERENCES}

1. D. K. Appel and J. I. Mickalonis, "Corrosion Coupon Rig Retrieval From Tank 50: Investigative Results And Recommendations," SRT-EES-950341, May, 251995.

2. ASTM G1-88, Standard Practice for Preparing, Cleaning, and Evaluating Corrosion Test Specimen, ASTM, Philadelphia, PA, 1995. 
WSRC-TR-95-0352

Table 1. The Exposure Condition and Corrosion For The Tank 50

Coupons Before Cleaning

\begin{tabular}{|c|c|c|c|c|}
\hline Number & Material & $\begin{array}{c}\text { Welding } \\
\text { Condition }\end{array}$ & Exposure & Description \\
\hline CW-1 & A106 & Welded & Air & $\begin{array}{l}\text { tubercle corrosion on } 40-50 \% \text { of surface } \\
\text { spotty rust on remaining surface } \\
\text { welds unattacked }\end{array}$ \\
\hline C-1 & A106 & Unwelded & Waste & $\begin{array}{l}\text { thin rust layer over most of surface } \\
\text { with black oxide scale } \\
\text { edges shiny with pinpoints of rust }\end{array}$ \\
\hline P-1 & A537 & Unwelded & Waste & $\begin{array}{l}\text { pinpoint rust spots over entire surface } \\
\text { reddish-brown coloring }\end{array}$ \\
\hline P-2 & A537 & Unwelded & $\begin{array}{l}\text { Air with } \\
\text { Interface }\end{array}$ & $\begin{array}{l}\text { tubercle corrosion on } 20-25 \% \text { of surface } \\
\text { in both the interfacial and air-exposed } \\
\text { sections } \\
\text { pinpoint rust spots also present }\end{array}$ \\
\hline W-1 & A537 & Welded & $\begin{array}{l}\text { Waste \& } \\
\text { Interface }\end{array}$ & $\begin{array}{l}\text { rust in spots on waste-exposed surface } \\
\text { one corner of coupon was exposed in } \\
\text { air and had a heavier rust layer }\end{array}$ \\
\hline $\mathrm{W}-2$ & A537 & Welded & $\begin{array}{l}\text { Waste \& } \\
\text { Interface }\end{array}$ & $\begin{array}{l}\text { few pinpoints of rust on waste-exposed } \\
\text { surface } \\
\text { one corner exposed to air and had } \\
\text { tubercle corrosion }\end{array}$ \\
\hline
\end{tabular}


Table 2. Weight Losses And Average Corrosion Rates For Tank 50 Coupons

\begin{tabular}{|c|c|c|c|c|c|c|}
\hline \multirow[b]{2}{*}{ Number } & \multicolumn{2}{|c|}{ Weight (g) } & \multirow{2}{*}{$\begin{array}{l}\text { Weight } \\
\text { Loss (g) }\end{array}$} & \multirow{2}{*}{$\begin{array}{l}\text { Adjst. } 1 \\
\text { Loss (g) }\end{array}$} & \multirow{2}{*}{$\begin{array}{c}\text { Surface } \\
\text { Area }\left(\text { in }^{2}\right)\end{array}$} & \multirow{2}{*}{$\begin{array}{l}\text { Corrosion } \\
\text { Rate (mpy) }\end{array}$} \\
\hline & Initial & Final & & & & \\
\hline $\begin{array}{c}\text { CW-1 } \\
\text { (A106) }\end{array}$ & 133.58 & 132.76 & 0.82 & 0.52 & 15.69 & 0.31 \\
\hline $\begin{array}{l}\text { C-1 } \\
\text { (A106) }\end{array}$ & 143.92 & 142.33 & 1.59 & 0.31 & 15.44 & 0.19 \\
\hline $\begin{array}{l}\text { P-1 } \\
\text { (A537) }\end{array}$ & 121.14 & 121.00 & 0.14 & 0.04 & 17.38 & 0.02 \\
\hline $\begin{array}{l}\text { P-2 } \\
\text { (A537) }\end{array}$ & 119.68 & 119.30 & 0.38 & 0.28 & 17.38 & 0.15 \\
\hline $\begin{array}{l}\text { W-1 } \\
\text { (A537) }\end{array}$ & 85.62 & 85.40 & 0.22 & 0.15 & 16.64 & 0.08 \\
\hline $\begin{array}{l}\text { W-2 } \\
\text { (A537) }\end{array}$ & 105.52 & 105.32 & 0.20 & 0.10 & 17.05 & 0.05 \\
\hline
\end{tabular}

1. Weights were adjusted for cleaning solution attack.

2. Corrosion rates (CR) were calculated from the adjusted losses (AL) and surface areas (SA) with the following equation:

$\mathrm{CR}(\mathrm{mpy})=\left\{\left[\mathrm{AL}(\mathrm{g}) / 128.64\left(\mathrm{~g} / \mathrm{in}^{3}\right)\right] /[\mathrm{SA}] 0.83(\mathrm{yr})\right\} 1000(\mathrm{mil} / \mathrm{in})$ 
Table 3. The Exposure Condition and Corrosion For The Tank 50 Coupons After Cleaning

\begin{tabular}{|c|c|c|c|c|}
\hline Number & Material & $\begin{array}{r}\text { Welding } \\
\text { Condition }\end{array}$ & Exposure & Description \\
\hline CW-1 & A106 & Welded & Air & $\begin{array}{l}\text { irregular surface under tubercles } \\
\text { rough surface under rust spots }\end{array}$ \\
\hline$C-1$ & Al06 & Unwelded & Waste & $\begin{array}{l}\text { rough surface under oxide scale } \\
\text { and pinpoint rust on edges }\end{array}$ \\
\hline P-1 & A537 & Unwelded & Waste & rough surface under rust spots \\
\hline $\mathrm{P}-2$ & A537 & Unwelded & $\begin{array}{l}\text { Air with } \\
\text { Interface }\end{array}$ & $\begin{array}{l}\text { irregular surface under tubercles } \\
\text { several areas with pits }\end{array}$ \\
\hline W-1 & A537 & Welded & $\begin{array}{l}\text { Waste \& } \\
\text { Interface }\end{array}$ & $\begin{array}{l}\text { waste-exposed surface smooth, did not } \\
\text { have significant attack } \\
\text { interfacial area had rough surface with } \\
\text { several pits }\end{array}$ \\
\hline W-2 & A537 & Welded & $\begin{array}{l}\text { Waste \& } \\
\text { Interface }\end{array}$ & $\begin{array}{l}\text { rough surface under rust spots } \\
\text { interfacial area had rough surface with } \\
\text { several pits }\end{array}$ \\
\hline
\end{tabular}




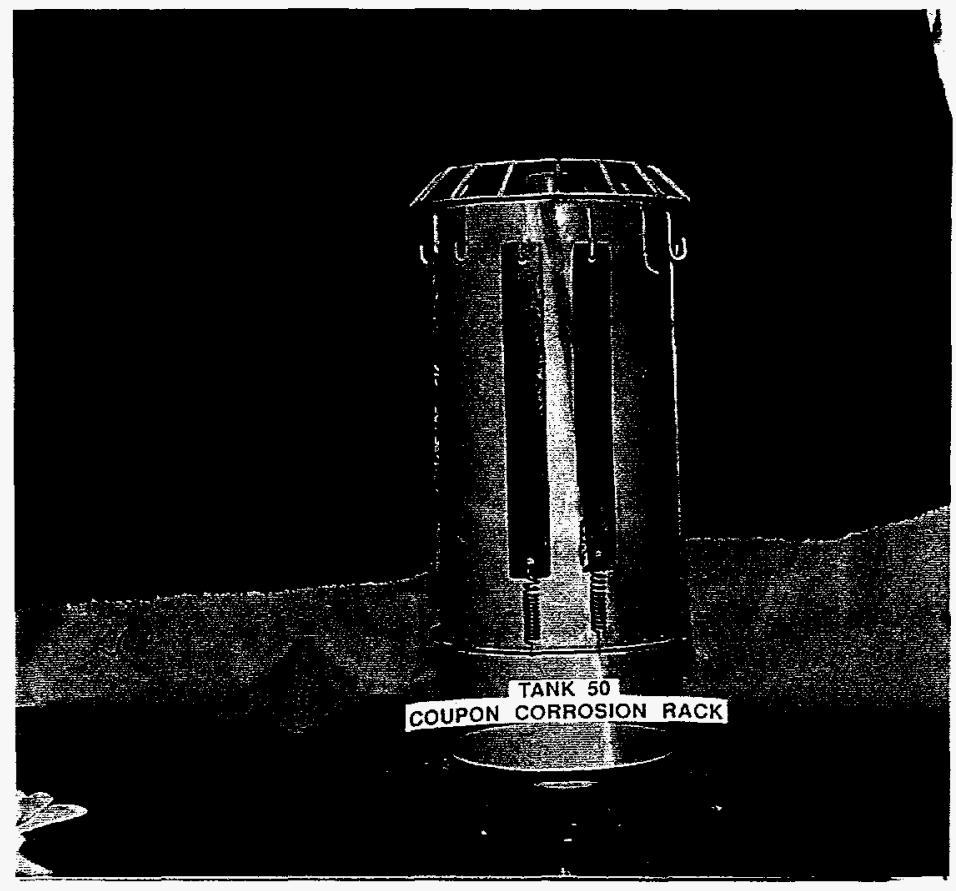

Figure 1. Floating rack of the Coupon Corrosion Rig from tank 50. The two coupons along the interface are P-2 (left) and W-1 (right). 


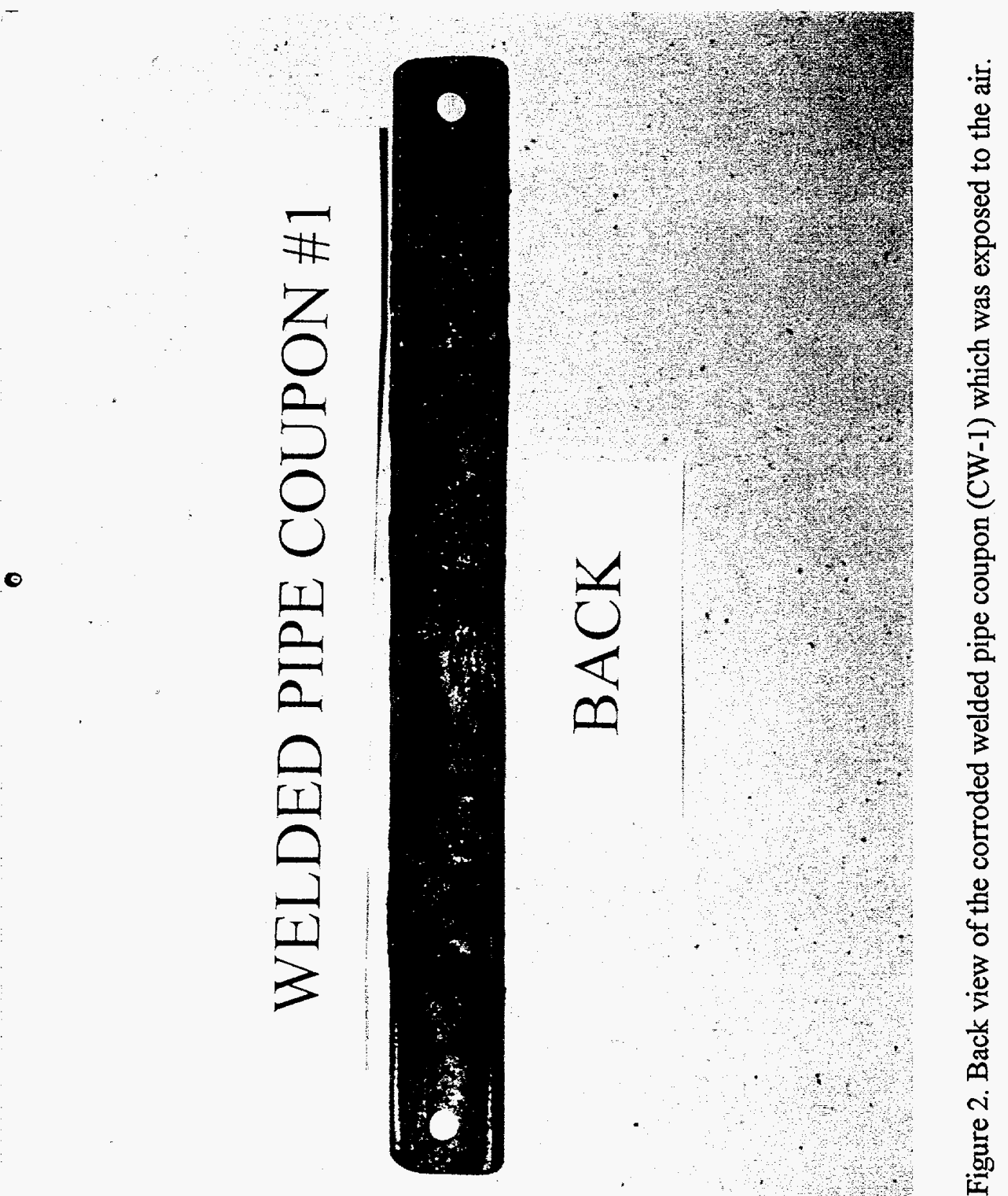




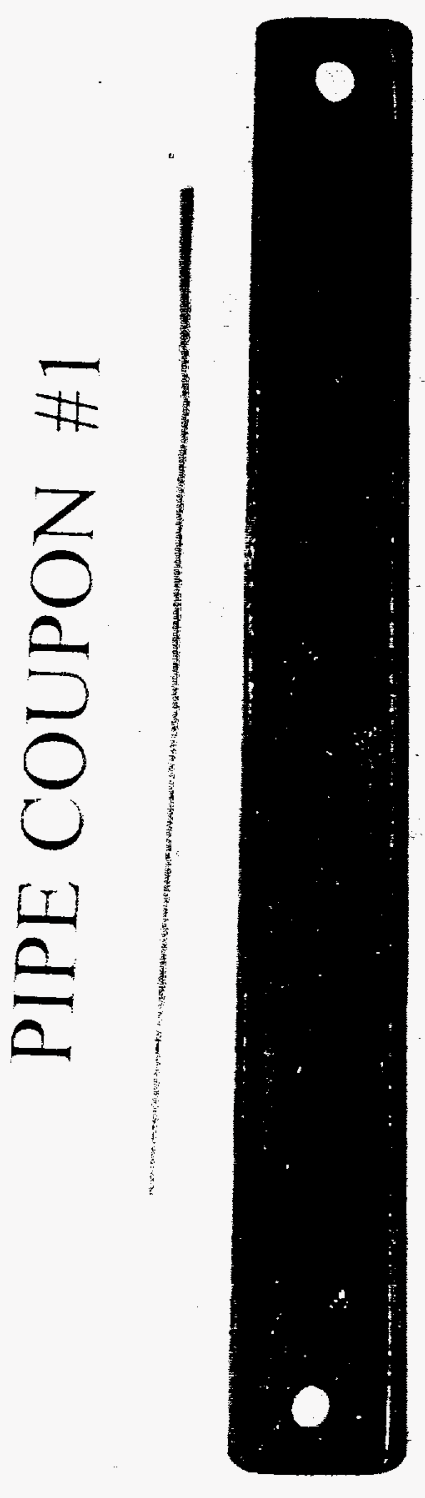

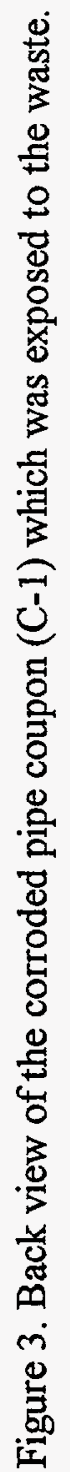




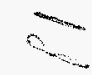

$-9$

3

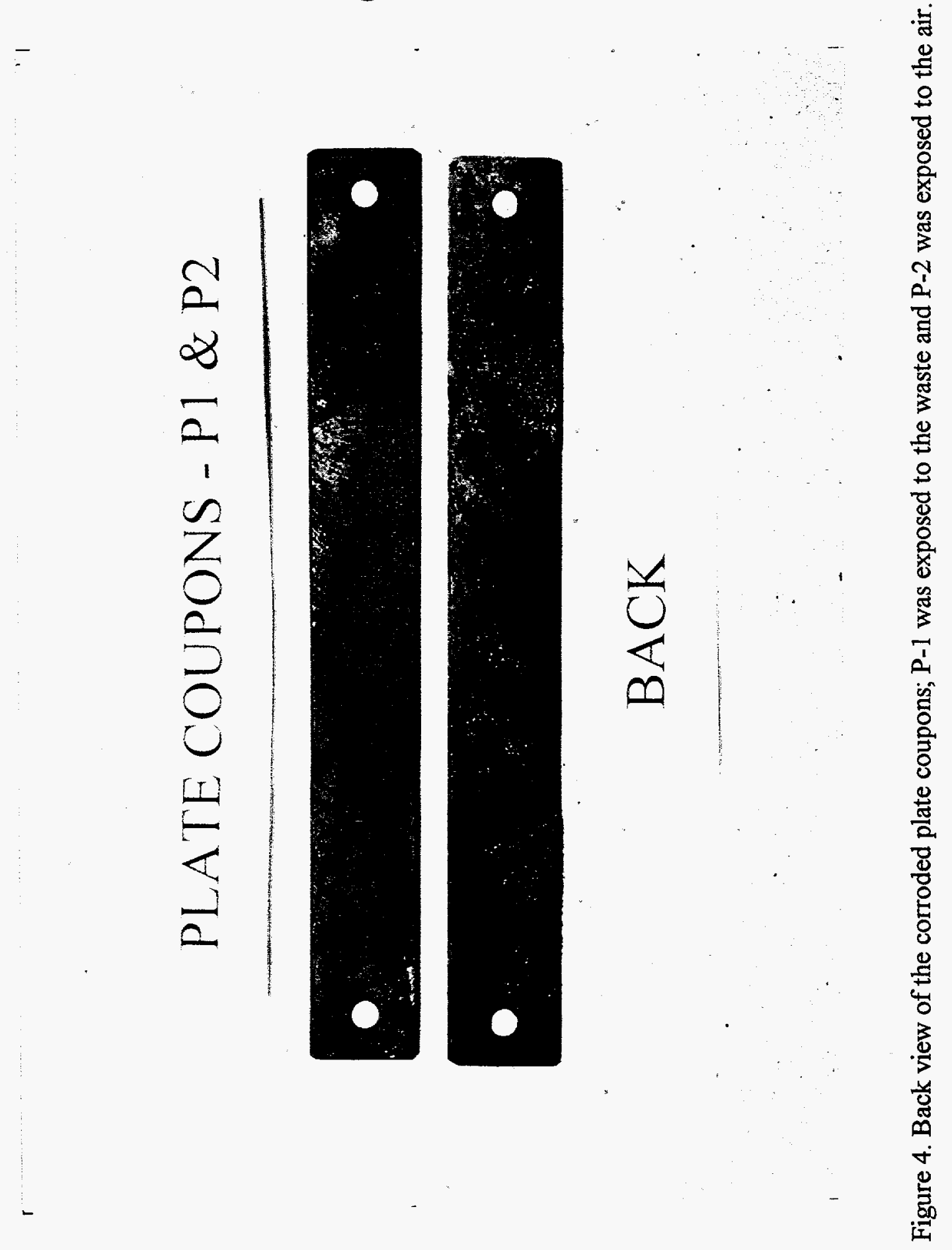



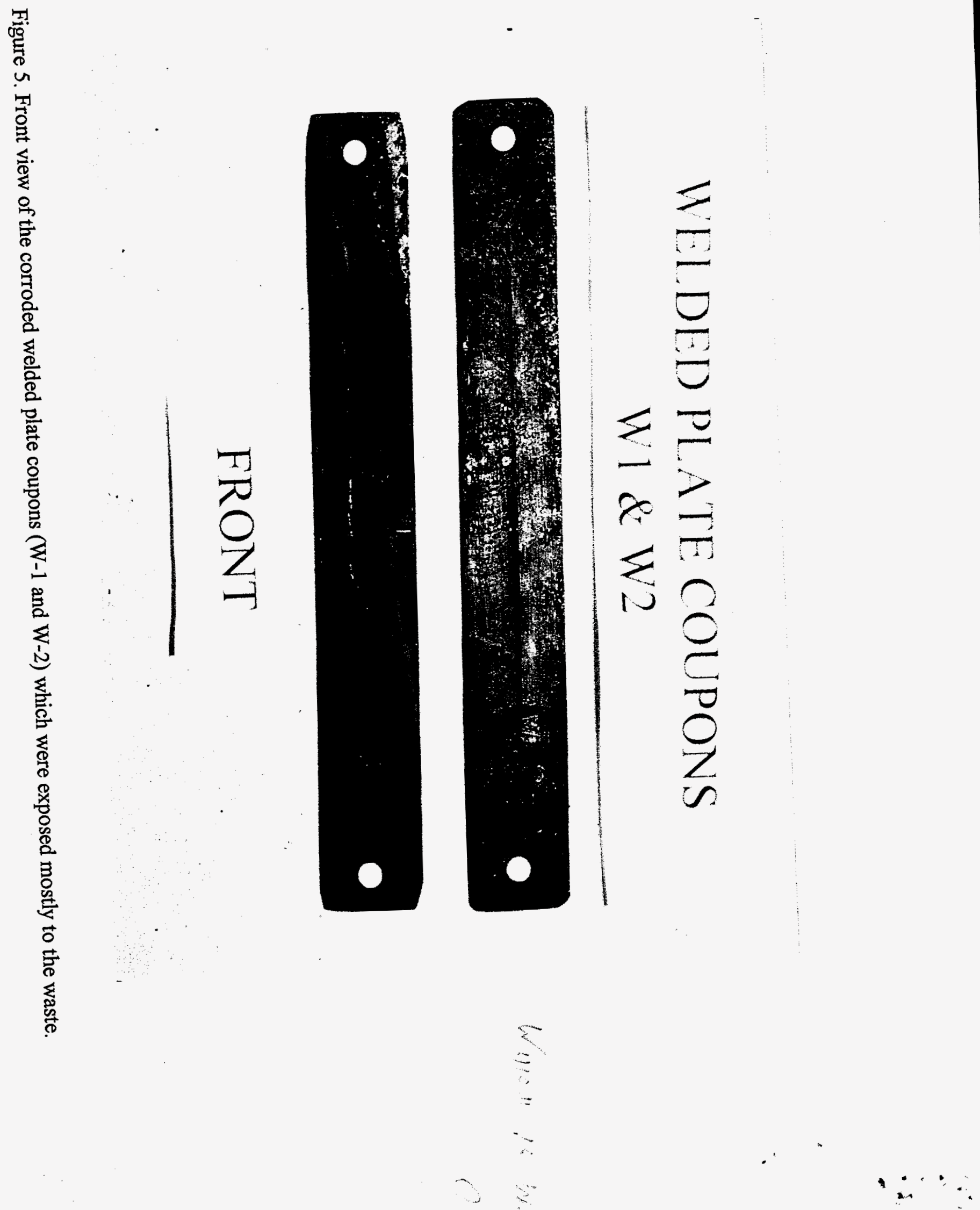